Environment Conservation Journal 15( 3)157-164, 2014

ISSN 0972-3099 (Print) 2278-5124 (Online)

Abstracted and Indexed

\title{
Impact of trace elements pollution of treated industrial effluent and its effect on soil and agriculture produce
}

\author{
R.P Mishra ${ }^{1} \bowtie$, S. K. Tripathi ${ }^{1}$, A. K. Mishra ${ }^{2}$ Arvind Mishra ${ }^{3}$ and S.C.Barman ${ }^{3}$ \\ Received: 25.01.2014 \\ Revised: 15.07.2014 \\ Accepted: 02.11.2014
}

\begin{abstract}
In the present study investigation on impact of treated and partially treated industrial effluents on soil and agriculture produce has been carried out. The study find out that parameters (pH, TSS, TDS, BOD, COD, Chloride, Sulphate, Zn, $\mathrm{Cu}, \mathrm{Pb}, \mathrm{Ni}, \mathrm{Cr}, \mathrm{Cd})$ of channel water of sampling station-I $\left(8.12,404 \mathrm{mgl}^{-1}, 2624 \mathrm{mgl}^{-1}, 122 \mathrm{mgl}^{-1}, 331.45 \mathrm{mgl}^{-1}, 808 \mathrm{mgl}^{-1}\right.$, $\left.32.4 \mathrm{mgl}^{-1}, 0.36 \mathrm{mgl}^{-1}, 0.05 \mathrm{mgl}^{-1}, 0.03 \mathrm{mgl}^{-1}, 0.04 \mathrm{mgl}^{-1}, 4.55 \mathrm{mgl}^{-1}, 0.03 \mathrm{mgl}^{-1}\right)$ was higher than station-II $\left(7.82,215 \mathrm{mgl}^{-1}\right.$, $\left.1737 \mathrm{mgl}^{-1}, 105 \mathrm{mgl}^{-1}, 265 \mathrm{mgl}^{-1}, 788 \mathrm{mgl}^{-1}, 29.7 \mathrm{mgl}^{-1}, 0.31 \mathrm{mgl}^{-1}, 0.04 \mathrm{mgl}^{-1}, 0.03 \mathrm{mgl}^{-1}, 0.034 .12 \mathrm{mgl}^{-1}, 0.02 \mathrm{mgl}^{-1}\right) . \mathrm{Waste}^{-1}$ water quality of stations I and II meet to exceed the Indian standard (IS: 2490) for BOD- $30 \mathrm{mgl}^{-1}, \mathrm{COD}^{-250} \mathrm{mgl}^{-1} \mathrm{and}^{-1}$ $\mathrm{Cr}-2 \mathrm{mgl}^{-1}$ for safe disposal of effluents into the surface water. During the course of study soil and agricultural produce has been collected from irrigation of treated or partial treated industrial effluent and analyzed for trace elements i.e. Fe, $\mathrm{Zn}, \mathrm{Cu}, \mathrm{Pb}, \mathrm{Ni}, \mathrm{Cr}$ and $\mathrm{Cd}$. The trace elements showed different enrichment factor for soil as $\mathrm{Cd} \mathrm{8.75(max),} \mathrm{Cr} 8.6, \mathrm{Zn}$ 5.73, $\mathrm{Ni}$ 4.08, Fe 3.16, Cu 2.41, Pb 1.58(min). For plant samples collected at polluted site showed different enrichment factor of trace elements - 6.87 $(\mathrm{Cr})>6.04(\mathrm{Zn})>3.34(\mathrm{~Pb})>3.05(\mathrm{Cu})>2.78(\mathrm{Fe})>2.30(\mathrm{Ni})>\mathrm{BDL}(\mathrm{Cd})$. The levels of trace elements concentration in spinach (max) (Fe821, Zn145, Cu19.84, Pb 18.04, Ni 10.1, Cr38.32, Cd0.88 $\mu$ g/g) and in wheat (min) (Fe326, Zn102, Cu8.23, Pb 12.6, Ni 5.9, Cr21.5, Cd0.21 $\mu$ g/g) grown on polluted soil were found more than the reference value of control sites in spinach (Fe257, Zn25, Cu6.98, Pb7.43, Ni4.13, Cr5.6, Cd BDL), which may create chronic health problem to living being through food chain . The highest enrichment factor of agricultural produce (EfpFe-2.78,Zn-6.04,Cu-3.05,Pb-3.34,Ni-2.3,Cr-6.87,Cd-0) was found for the element of $\mathrm{Cr}$ and for soil, the highest enrichment factor (Efs- - Fe-3.16, $\mathrm{Zn}-5.73, \mathrm{Cu}-2.41, \mathrm{~Pb}-1.58, \mathrm{Ni}-4.08, \mathrm{Cr}-8.6, \mathrm{Cd}-8.75)$ was found for element of $\mathrm{Cd}$ respectively.
\end{abstract}

Keywords:agriculture produce, effluent, enrichment factor, pollution, soil, trace elements

\section{Introduction}

Large numbers of tanneries were located at Jajmau, Kanpur which is one of the major centers for the processing of raw hides. These industries and sewage wastewater is being treated in treatment plant. The treated wastewater is being used for more than two decades for the irrigation of crops and vegetable. According to local information all the plants are adversely affected by contaminated irrigation water. Complaints have been made regarding the deterioration of health of the local inhabitants consuming the local plants produce and using ground water for drinking. There are frequent complaints of water born diseases among people using water from Jajmau area. According to Raj et al.,(1996) tanneries, oil refineries and metal industries are causing depletion of surface and

\footnotetext{
Author's Address

${ }^{1}$ Department of Energy and Environmental Science, Mahatma Gandhi ChitrakootGramodaya Vishwavidyalaya, Chitrakoot

${ }^{2}$ Department of Chemical Engineering, H.B.T.I. Kanpur

${ }^{3}$ Indian Institute of Toxicology Research, Lucknow E-mail:ravihh@gmail.com
}

ground water quality. Khwaja et al., (2001) stated that the major components of the tannery effluents are the toxic trace metals. Presence of heavy metals in soil is known to have potential toxic impact on environmental quality and on human health via ground water and surface water (Mishra and Pandey, 2005; Akinola and Ekiyoyo, 2006). The use of wastewater is now a big problem due to the presence of pollutants particularly heavy metals, however, it is being used for the irrigation of agricultural produce. Long-term irrigation can changes the quality of agricultural soil and trace element inputs which sustained over long period (Barman et al., 2001; Gothberg et al., 2002; Sinha et al., 2005, 2006). More over concentration of heavy metals in soil may render soils non productive because of phytotoxicity and may cause bioaccumulation of heavy metals in human beings (Abdel-Sahab et al., 1994; Memon et al. ,2001; Singh et al., 2006). Polluted water, in addition to other effects, directly affects soil not only in 
industrial area but also in agricultural fields as well as the beds of rivers, creating secondary sources of pollution (De et al., 1980, 1985; Ray and Banerjee., 1983; Ray et al., 1988; Barman and Lal., 1994; Kisku et al., 2000; Barman et al., 2001). Temmerman et al., (1984) reported the upper limit of metals $\left(\mu \mathrm{gg}^{-1}\right)$ in non polluted sandy soil; $\mathrm{Cd}$ (1.00), Cr (15), Co (5), Cu (15), $\mathrm{Hg}$ (0.15), Mn (500), Mo (5), Ni (1), Pb (50), Zn (100). The unregulated use of chromium in many industries has led to the contamination of soil, sediments, surface, and ground water (Barnhart, 1997; Kotas and Stasicka, 2000; Singh and Sinha., 2004a) which causes several environmental problems due to its extreme toxicity to living organism. Similar to other metals, $\mathrm{Cr}$ in trace amounts is beneficial to humans, animals, plants and microorganism (Nielsen, 1998). However, at higher concentrations, it is detrimental to health. Keeping this objective in mind the present study was undertaken to assess the trace elements in the treated effluents discharged from tanneries and their impact on soil and plants irrigated with waste water for a long time.

\section{Material and methods}

Samples of effluent water were taken from two locations- Station-1 (confluence point of channel receiving effluent), and Station-2 which is $5 \mathrm{~km}$ downstream from the first location and analyzed for their quality.The control sites was irrigated by ground water which is situated near about $16 \mathrm{~km}$ distance from Station I \& II (Fig. 1). The physicochemical parameters were estimated as per standard procedure (APHA, 2005). Agriculture produce and soil samples were collected during March-April, 2010 from wastewater irrigated area in Jajmau. The wastewater is being used for more than two decades for the irrigation of crops and vegetable. Six edible plants of different species and top productive soil $(0-30 \mathrm{~cm})$ samples were collected randomly from polluted site. Soil samples were free from extraneous matter (stones, pebbles etc) and airdried. After air-drying, the samples were ground and sieved through $2 \mathrm{~mm}$ sieve to ensure uniform particle size. The soil samples were analyzed for $\mathrm{pH}$, electrical conductivity, bulk density, porosity, organic matter, nitrite, nitrate, inorganic phosphate

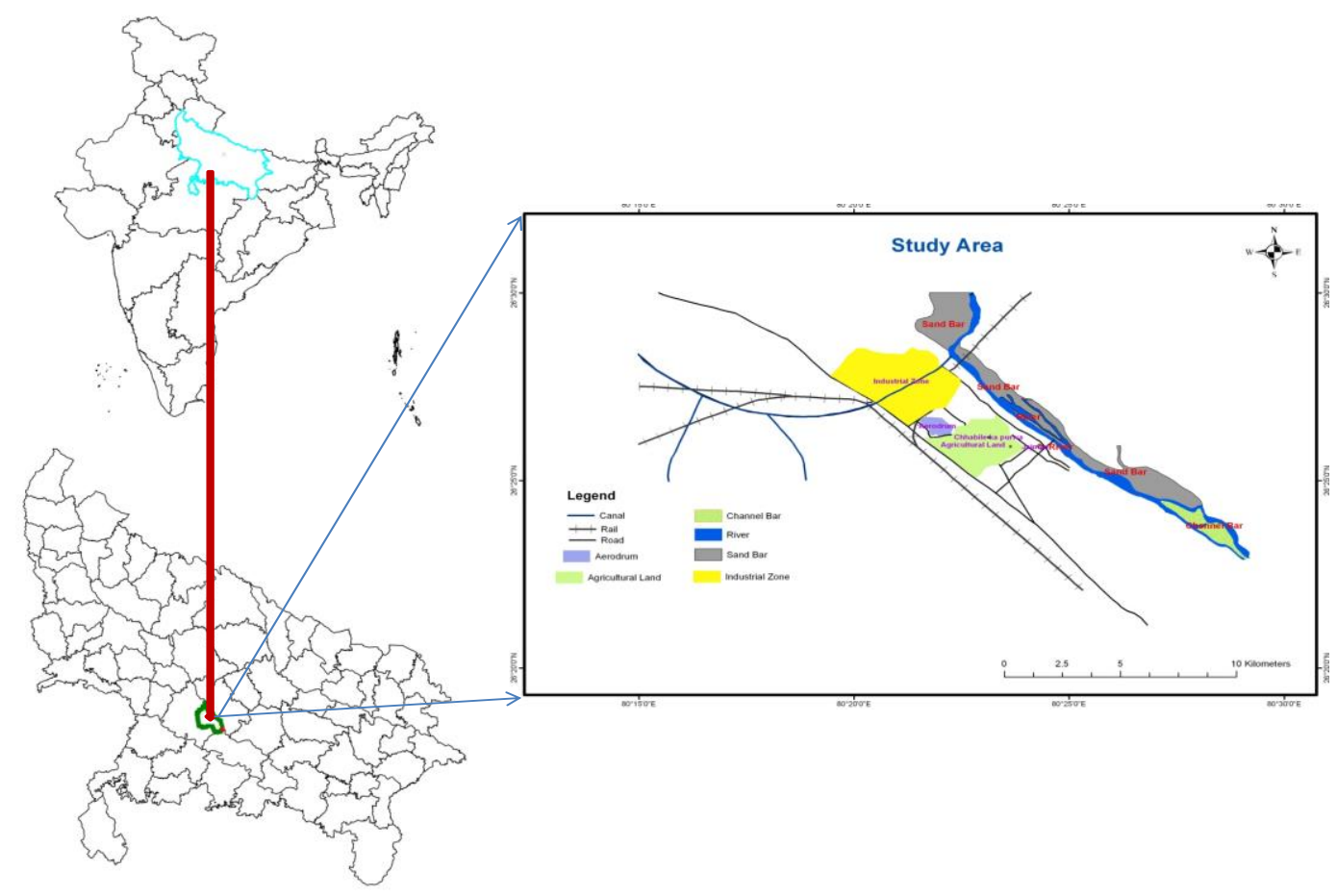

Fig. 1: Map of the study area 
and chloride which have a bearing on the availability of trace elements to the plants (Sahuet al., 2007). Soil and plant samples were analyzed for the trace elements- $\mathrm{Fe}, \mathrm{Zn}, \mathrm{Cu}, \mathrm{Pb}, \mathrm{Ni}, \mathrm{Cr}$ and $\mathrm{Cd}$ using Atomic Absorption Spectrophotometer (AAS). Samples were digested with $\mathrm{HNO}_{3}-\mathrm{HClO}_{4}$ mixture following the method of Barman and Lal (1994). Plant samples were taken in mature stage. For each sample, nine plants were collected and $70^{\circ} \mathrm{C}$ for $24 \mathrm{~h}$, grind and mixed thoroughly for metal analysis. All analyses were done in triplicate.

Control soil and plant samples receiving ground water irrigation from deep bore well were also collected at a distance of near about $16 \mathrm{~km}$ from polluted site having similar soil profile and climate condition. This area is free from industry. Enrichment factors (Efs/Efp) (Kisku et al., 2000) were calculated by fallowing formula:

$\mathrm{Efs} / \mathrm{Efp}=\frac{\text { Concentration of the metal in soil or plant at contaminated site }}{\text { Concentration of the metal in soil or plant at uncontaminated site }}$

\section{Results and discussion}

Water analysis: The average value of $\mathrm{pH}$, TSS, TDS, BOD, COD, Chloride, Sulphate were found $8.12,404 \mathrm{mg} / \mathrm{l}, 2624 \mathrm{mg} / \mathrm{l}, 122 \mathrm{mg} / \mathrm{l}, 331.45 \mathrm{mg} / \mathrm{l}$, $808 \mathrm{mg} / \mathrm{l}, 32.4 \mathrm{mg} / \mathrm{l}$ at Station-I and 7.82, $215 \mathrm{mg} / \mathrm{l}$, $1737 \mathrm{mg} / \mathrm{l}, 105 \mathrm{mg} / \mathrm{l}, 265 \mathrm{mg} / \mathrm{l}, 788 \mathrm{mg} / \mathrm{l}, 29.7 \mathrm{mg} / \mathrm{l}$ at Station-II and control area (Tubell water) $\mathrm{pH}$ 7.82, TSS-38 mg/l, TDS-314 mg/l, Chloride- 45 $\mathrm{mg} / \mathrm{l}$, Sulphate-13 $\mathrm{mg} / \mathrm{l}$ at respectively (Table-1).

The chemical parameters of station-I was showed higher concentration ( $\mathrm{pH}-8.12$, TSS- $404 \mathrm{mg} / \mathrm{l}$, TDS-2624 mg/l, BOD-122 mg/l, COD-331.45 mg/l, Chloride- $808 \mathrm{mg} / \mathrm{l}$, Sulphate- $32.4 \mathrm{mg} / \mathrm{l}$ ) than at Station-II (pH-7.82, TSS-215 mg/l, TDS-1737 $\mathrm{mg} / \mathrm{l}$, BOD-105 mg/l, COD- $265 \mathrm{mg} / \mathrm{l}$, Chloride$788 \mathrm{mg} / \mathrm{l}$, Sulphate- $29.7 \mathrm{mg} / \mathrm{l}$ ) this may be because Station-I was near to outlet. The control site irrigation water qualities were found under the permissible limit. The analysed parameters of irrigation water like TSS, TDS, BOD and COD were found much higher (404 mg/l, $2624 \mathrm{mg} / \mathrm{l}, 122$ $\mathrm{mg} / \mathrm{l}, 331.45 \mathrm{mg} / \mathrm{l}$,) than their respective standards $100 \mathrm{mg} / \mathrm{l}, 2100 \mathrm{mg} / \mathrm{l}, 30 \mathrm{mg} / \mathrm{l}$, and $250 \mathrm{mg} / \mathrm{l}$ for the final discharged of the industrial effluent water into the inland surface water (IS: 2490, 1981). Irrigation channel water at both sampling station were not found suitable for irrigation, our result are in agreement with several workers who reported that because of improper treatment high chemical load was found in the discharged tannery effluents (Karagul et al.,2005; Malaviya and Rathore, 2007).

The average concentrations of trace elements likes $\mathrm{Zn}, \mathrm{Cu}, \mathrm{Pb}, \mathrm{Ni}, \mathrm{Cr}$, and $\mathrm{Cd}$ were found $0.36 \mathrm{mg} / \mathrm{l}$, $0.05 \mathrm{mg} / \mathrm{l}, 0.03 \mathrm{mg} / \mathrm{l}, 0.04 \mathrm{mg} / \mathrm{l}, 4.55 \mathrm{mg} / \mathrm{l}, 0.03$ $\mathrm{mg} / \mathrm{l}$ at Station-I, at Station-II were found 0.31 $\mathrm{mg} / \mathrm{l}, 0.04 \mathrm{mg} / \mathrm{l}, 0.03 \mathrm{mg} / \mathrm{l}, 0.03 \mathrm{mg} / \mathrm{l}, 4.12 \mathrm{mg} / \mathrm{l}$, $0.02 \mathrm{mg} / \mathrm{l}$ and $0.094 \mathrm{mg} / \mathrm{l}, 0.012 \mathrm{mg} / \mathrm{l}, 0.012 \mathrm{mg} / \mathrm{l}$, $0.007 \mathrm{mg} / \mathrm{l}, 0.016 \mathrm{mg} / \mathrm{l}, \mathrm{BDL} \mathrm{mg} / \mathrm{l}$ at control site respectively (Table-I). Except $\mathrm{Cr}$, other observed values i.e $\mathrm{Zn}, \mathrm{Cu}, \mathrm{Pb}, \mathrm{Ni}, \mathrm{Cr}$ and $\mathrm{Cd}$ are found lower than their prescribed standard $5.0 \mathrm{mg} / \mathrm{l}, 3.0$ $\mathrm{mg} / \mathrm{l}, \quad 0.1 \mathrm{mg} / \mathrm{l}, \quad 3.0 \mathrm{mg} / \mathrm{l}, \quad 2.0 \mathrm{mg} / \mathrm{l}, \quad 2.0 \mathrm{mg} / \mathrm{l}$ respectively for safe disposal of treated effluent into the inland surface water (IS : 2490,1981). However, chromium concentrations approach the higher limit for disposal (Kannan et al., 2005).

Soils analysis: The average value of $\mathrm{pH}$ in polluted soil was found as 7.97 and 7.35 in unpolluted soil. The natures of polluted soil was alkaline this may be due to the continuous receiving of tannery effluents. Average concentrations of chloride and nitrate were found $80.2 \mathrm{mg} / \mathrm{g}$ and $0.66 \mathrm{mg} / \mathrm{g}$ in polluted soil while $26.2 \mathrm{mg} / \mathrm{g}$ and $0.33 \mathrm{mg} / \mathrm{g}$ respectively in unpolluted soil (Table-2).

The porosity and organic matter percentage differ from polluted soil $(34.9 \% \& 9.8 \%)$ in comparison to unpolluted soil $(50.1 \%$ and $15.6 \%$ ) (Table-2). These two soil fertility parameters; porosity which collect enough water and air for plant growth and organic matter were markedly decreased due to the receiving of contaminated wastewater (Sahuet al.,2007). Bulk density of polluted soil was found as $1.21 \mathrm{gm} / \mathrm{cc}$ and for unpolluted soil it was observed as 1.1. According to Kolay, 2000 the sandy soil and clay soil should not be more than 1.4 $\mathrm{gm} / \mathrm{cc}$ and $1.2 \mathrm{gm} / \mathrm{cc}$ respectively for optimum crop growth.The average trace elements concentrations of polluted soil were found in $\mathrm{Fe}\left(737.4 \mu \mathrm{g} \mathrm{g}^{-1}\right), \mathrm{Zn}$ $\left(212 \mu \mathrm{g} \mathrm{g}^{-1}\right), \mathrm{Cu}\left(34.75 \mu \mathrm{g} \mathrm{g}^{-1}\right), \mathrm{Pb}\left(24.45 \mu \mathrm{g} \mathrm{g}^{-1}\right)$, $\mathrm{Ni}\left(16.73 \mu \mathrm{g} \mathrm{g}^{-1}\right), \mathrm{Cr}\left(164.43 \mu \mathrm{g} \mathrm{g}^{-1}\right), \mathrm{Cd}(1.75 \mu \mathrm{g}$ $\left.\mathrm{g}^{-1}\right)$ d.w. where as in case of unpolluted soil it was found almost in the same sequence of $\mathrm{Fe}(233 \mu \mathrm{g} \mathrm{g}$ $\left.{ }^{1}\right), \mathrm{Zn}\left(37 \mu \mathrm{g} \mathrm{g}^{-1}\right), \mathrm{Cu}\left(14.4 \mu \mathrm{g} \mathrm{g}^{-1}\right), \mathrm{Pb}(15.5 \mu \mathrm{g} \mathrm{g}$ $\left.{ }^{1}\right), \mathrm{Ni}\left(4.1 \mu \mathrm{g} \mathrm{g}^{-1}\right), \mathrm{Cr}\left(19.12 \mu \mathrm{g} \mathrm{g}^{-1}\right), \mathrm{Cd}\left(0.2 \mu \mathrm{g} \mathrm{g}^{-1}\right)$ d.w. respectively in unpolluted soil (Table-2). Polluted soil showed different enrichment factor$8.75(\mathrm{Cd})>8.6(\mathrm{Cr})>5.73(\mathrm{Zn})>4.08(\mathrm{Ni})>3.16$ $(\mathrm{Fe})>2.41(\mathrm{Cu})>1.58(\mathrm{~Pb})$ times higher trace 
Mishra et al.

Table-1: Study of water quality at station I, station II and control area

\begin{tabular}{|c|c|c|c|c|c|}
\hline \multirow{2}{*}{ S.N. } & \multirow{2}{*}{ Parameter } & \multirow{2}{*}{ Unit } & \multicolumn{3}{|c|}{ Study Area } \\
\cline { 4 - 6 } & & & Station-I & Station-II & Control Area \\
\hline 1 & Color & Visual & Light Gray & Light Gray & Colorless \\
\hline 2 & Odor & -- & Unpleasant & Unpleasant & Odorless \\
\hline 3 & TSS & $\mathrm{mgl}^{-1}$ & 404 & 215 & 38 \\
\hline 4 & TDS & $\mathrm{mgl}^{-1}$ & 2624 & 1737 & 314 \\
\hline 5 & $\mathrm{TS}$ & $\mathrm{mgl}^{-1}$ & 3028 & 1952 & 352 \\
\hline 6 & $\mathrm{pH}$ & & 8.12 & 7.82 & 7.57 \\
\hline 7 & $\mathrm{BOD}$ & $\mathrm{mgl}-1$ & 122 & 105 & ----- \\
\hline 8 & $\mathrm{COD}$ & $\mathrm{mgl}-1$ & 331.45 & 265 & ----- \\
\hline 9 & $\mathrm{Chloride}$ & $\mathrm{mgl}-1$ & 808 & 788 & 45 \\
\hline 10 & $\mathrm{Sulphate}$ & $\mathrm{mgl}-1$ & 32.4 & 29.7 & 13 \\
\hline 11 & $\mathrm{Zn}$ & $\mathrm{mgl}-1$ & 0.36 & 0.31 & 0.094 \\
\hline 12 & $\mathrm{Cu}$ & $\mathrm{mgl}-1$ & 0.05 & 0.04 & 0.012 \\
\hline 13 & $\mathrm{~Pb}$ & $\mathrm{mgl}-1$ & 0.03 & 0.03 & 0.012 \\
\hline 14 & $\mathrm{Ni}$ & $\mathrm{mgl}-1$ & 0.04 & 0.03 & 0.007 \\
\hline 15 & $\mathrm{Cr}$ & $\mathrm{mgl}-1$ & 4.55 & 4.12 & 0.016 \\
\hline 16 & $\mathrm{Cd}$ & $\mathrm{mgl}-1$ & 0.03 & 0.02 & BDL \\
\hline
\end{tabular}

Table2: Average concentrations of different parameter of unpolluted soil and polluted soil

\begin{tabular}{|l|c|c|c|c|}
\hline S.N. & Parameters & Unit & Control Area & Study Area \\
\hline 1 & $\mathrm{pH}$ & & 7.35 & 7.97 \\
\hline 2 & Electrical Conductivity & $\mu \mathrm{S} \mathrm{cm}-1$ & 212 & 387 \\
& & & & \\
\hline 3 & Bulk density & $\mathrm{gm} / \mathrm{cc}$ & 1.1 & 1.21 \\
\hline 4 & Porosity & $\%$ & 50.1 & 34.9 \\
\hline 5 & Organic matter & $\%$ & 15.6 & 9.8 \\
\hline 6 & Chloride & $\mathrm{mg} \mathrm{g}^{-1}$ & 26.2 & 80.2 \\
\hline 7 & Nitrate & $\mathrm{mg} \mathrm{g}^{-1}$ & 0.33 & 0.66 \\
\hline 8 & $\mathrm{Fe}$ & $\mu \mathrm{g} \mathrm{g}^{-1}$ & 233 & 737.4 \\
\hline 9 & $\mathrm{Zn}$ & $\mu \mathrm{g} \mathrm{g}^{-1}$ & 37 & 212 \\
\hline 10 & $\mathrm{Cu}$ & $\mu \mathrm{g} \mathrm{g}^{-1}$ & 14.4 & 34.75 \\
\hline 11 & $\mathrm{~Pb}$ & $\mu \mathrm{g} \mathrm{g} \mathrm{g}^{-1}$ & 15.5 & 24.45 \\
\hline 12 & $\mathrm{Ni}$ & $\mu \mathrm{g} \mathrm{g}^{-1}$ & 4.1 & 16.73 \\
\hline 13 & $\mathrm{Cr}$ & $\mu \mathrm{g} \mathrm{g}^{-1}$ & 19.12 & 164.43 \\
\hline 14 & $\mathrm{Cd}$ & 0.2 & 1.75 \\
\hline
\end{tabular}

elements level than unpolluted soil. Increases of The levels of trace elements concentration in the such trace elements in soil irrigated with spinach (max) $\left(\mathrm{Fe} 821 \mu \mathrm{g} \mathrm{g}^{-1}, \mathrm{Zn} 145 \mu \mathrm{g} \mathrm{g}^{-1}, \mathrm{Cu}\right.$ industrial effluent may be the source of $19.84 \mu \mathrm{g} \mathrm{g}^{-1}, \mathrm{~Pb} 18.04 \mu \mathrm{g} \mathrm{g}^{-1}, \mathrm{Ni} 10.1 \mu \mathrm{g} \mathrm{g}^{-1}, \mathrm{Cr}$ bioaccumulation in agriculture plant grown on this $38.32 \mu \mathrm{g} \mathrm{g}^{-1}, \mathrm{Cd} 0.88 \mu \mathrm{g} \mathrm{g}^{-1}$ ) and in wheat (min) land which not only affect the yield/ hectare but (Fe $326 \mu \mathrm{g} \mathrm{g}^{-1}, \mathrm{Zn} 102 \mu \mathrm{g} \mathrm{g}^{-1}, \mathrm{Cu} 8.23 \mu \mathrm{g} \mathrm{g}^{-1}, \mathrm{~Pb}$ also fare chance to pass on to food web (Nath et al., $12.6 \mu \mathrm{g} \mathrm{g}^{-1}$, Ni $5.9 \mu \mathrm{g} \mathrm{g}^{-1}$, Cr $21.5 \mu \mathrm{g} \mathrm{g}^{-1}, \mathrm{Cd}_{0.21}$ 2005; Hooda, 2007).

$\mu \mathrm{g} \mathrm{g}^{-1}$ ) grown on polluted soil were found more Agriculture produce: The Plant samples of than the reference value of control sites, These polluted site also showed different enrichment results shows that irrigation channel water enriches factor (metal vies) - $6.87(\mathrm{Cr})>6.04(\mathrm{Zn})>3.34$ the trace elements content. Enrichment of the trace $(\mathrm{Pb})>3.05(\mathrm{Cu})>2.78(\mathrm{Fe})>2.30(\mathrm{Ni})>\mathrm{BDL}(\mathrm{Cd}) . \quad$ elements content in water and soil shows greater 
uptake (Fig. 2,3), translocation and retention of $\mu \mathrm{g} \mathrm{g}^{-1}$ spinach (whole plant), Ni $10.1 \mu \mathrm{g} \mathrm{g}^{-1}$ spinach metal in different tissues (Li et al., 2003; Greger (whole plant), $\mathrm{Pb} 18.04 \mu \mathrm{g} \mathrm{g}^{-1}$ spinach (whole and Lofstedt, 2004; Boularbah et al., 2006). The plant), Cd $0.88 \mu \mathrm{g} \mathrm{g}^{-1}$ spinach (whole plant), Cu 19. trace elements level of $\mathrm{Fe} 821 \mu \mathrm{g} \mathrm{g}^{-1}$ spinach $84 \mu \mathrm{g} \mathrm{g}^{-1}$ spinach (whole plant) of metalswere found (whole plant), Zn $145 \mu \mathrm{g} \mathrm{g}^{-1}$ spinach (whole plant), in plant on polluted site (Table-3,4).

Cr 38.32

Table3: Average concentration $\left(\mu \mathrm{g} \mathrm{g}^{-1)}\right.$ of trace elements in different plants grown on polluted soil

\begin{tabular}{|c|c|c|c|c|c|c|c|}
\hline Plant name & $\begin{array}{c}\mathbf{F e} \\
\left(\mu \mathrm{g} \mathrm{g}^{-1}\right)\end{array}$ & $\begin{array}{l}\mathbf{Z n} \\
\left(\mu \mathrm{g} \mathrm{g}^{-1}\right)\end{array}$ & $\begin{array}{c}\mathrm{Cu} \\
\left(\mu \mathrm{g} \mathrm{g}^{-1}\right)\end{array}$ & $\begin{array}{c}\mathbf{P b} \\
\left(\mu \mathrm{g} \mathrm{g}^{-1}\right)\end{array}$ & $\begin{array}{c}\mathbf{N i} \\
\left(\mu \mathrm{g} \mathrm{g}^{-1}\right)\end{array}$ & $\begin{array}{c}\mathrm{Cr} \\
\left(\mu \mathrm{g} \mathrm{g}^{-1}\right)\end{array}$ & $\begin{array}{c}\mathbf{C d} \\
\left(\mu \mathrm{g} \mathrm{g}^{-1}\right)\end{array}$ \\
\hline Spinach (Spinacia oleracea) & 821 & 145 & 19.84 & 18.04 & 10.1 & 38.32 & 0.88 \\
\hline Wheat (Triticum aestivum) & 326 & 102 & 8.23 & 12.6 & 5.9 & 21.5 & 0.21 \\
\hline $\begin{array}{l}\text { Black Musterd } \\
\text { (Brassica campestries) }\end{array}$ & 690 & 121 & 13.43 & 17.1 & 7.81 & 29.2 & 0.63 \\
\hline Potato (Solanum tuberosum) & 495 & 125 & 16.2 & 25.3 & 7.09 & 22.34 & 0.41 \\
\hline Cabbage(Brassica oleracea) & 750 & 130 & 14.2 & 16.6 & 8.3 & 33.02 & 0.61 \\
\hline Cucumber (Cucumus melo) & 474.5 & 105 & 17.61 & 14.01 & 4.12 & 27.94 & 0.52 \\
\hline Cultivated plant Avg & 592.8 & 121.3 & 14.92 & 17.28 & 7.22 & 28.72 & 0.54 \\
\hline
\end{tabular}

Table 4: Average concentration $\left(\mu \mathrm{g} \mathrm{g}^{-1}\right)$ of trace elements in different plants grown at control site.

\begin{tabular}{|c|c|c|c|c|c|c|c|}
\hline Plant name & $\begin{array}{c}\mathbf{F e} \\
\left(\mu \mathrm{g} \mathrm{g}^{-1}\right)\end{array}$ & $\begin{array}{c}\mathrm{Zn} \\
\left(\mu \mathrm{g} \mathrm{g}^{-1}\right)\end{array}$ & $\underset{\left(\mu \mathrm{g} \mathrm{g} \mathbf{g}^{-1}\right)}{\mathbf{C u}}$ & $\begin{array}{c}\mathrm{Pb} \\
\left(\mu \mathrm{g} \mathrm{g} \mathrm{g}^{-1}\right)\end{array}$ & $\begin{array}{c}\mathrm{Ni} \\
\left(\mu \mathrm{g} \mathrm{g}^{-1}\right)\end{array}$ & $\begin{array}{c}\mathrm{Cr} \\
\left(\mu \mathrm{g} \mathrm{g}^{-1}\right)\end{array}$ & $\underset{\left(\mu \mathrm{g} \mathrm{g^{-1 }}\right)}{\mathbf{C d}}$ \\
\hline $\begin{array}{l}\text { Spinach } \\
\text { (Spinacia oleracea) }\end{array}$ & 257 & 25 & 6.98 & 7.43 & 4.13 & 5.6 & BDL \\
\hline $\begin{array}{l}\text { Wheat } \\
\text { (Triticum aestivum) }\end{array}$ & 159 & 12 & 3.7 & 3.1 & 1.81 & 3.1 & BDL \\
\hline $\begin{array}{l}\text { Black Musterd } \\
\text { (Brassica campestries) }\end{array}$ & 240 & 20 & 4.02 & 6.1 & 4.03 & 4.16 & BDL \\
\hline $\begin{array}{l}\text { Potato } \\
\text { (Solanum tuberosum) }\end{array}$ & 210 & 18.5 & 4.34 & 4.5 & 4.25 & 4.1 & BDL \\
\hline $\begin{array}{l}\text { Cabbage } \\
\text { (Brassica oleracea) }\end{array}$ & 228 & 26 & 5.38 & 5.9 & 2.5 & 4.32 & BDL \\
\hline $\begin{array}{l}\text { Cucumber } \\
\text { (Cucumus melo) }\end{array}$ & 185 & 19 & 4.88 & 4 & 2.1 & 3.8 & BDL \\
\hline Cultivated plant Avg. & 213.17 & 20.08 & 4.88 & 5.17 & 3.14 & 4.18 & -- \\
\hline
\end{tabular}

$(\mathrm{n}=3, \mathrm{BDL}=$ Below Detection Limit $)$ 


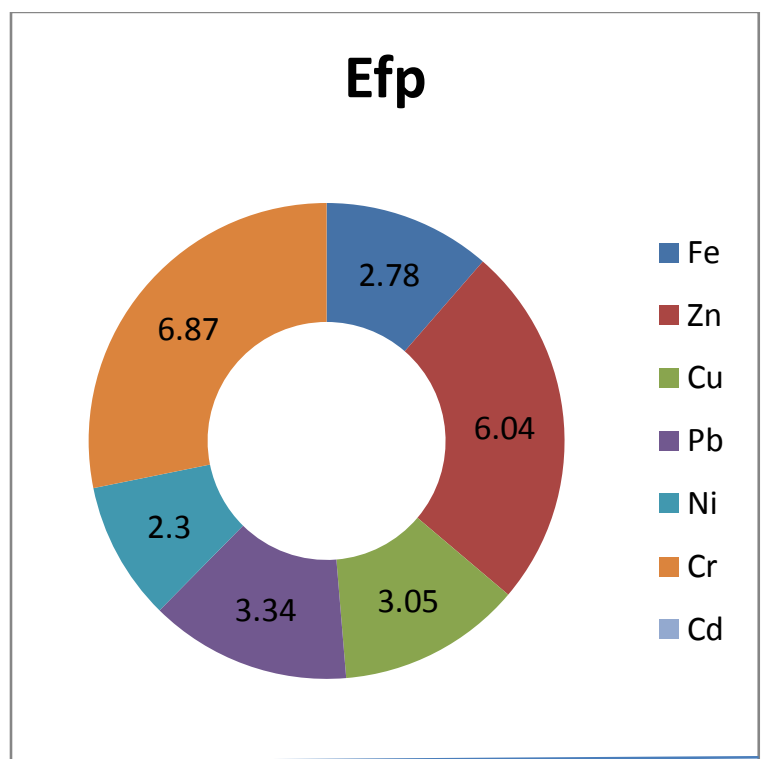

Fig.2: Enrichment factor of agriculture produce (Efp) of different trace elements

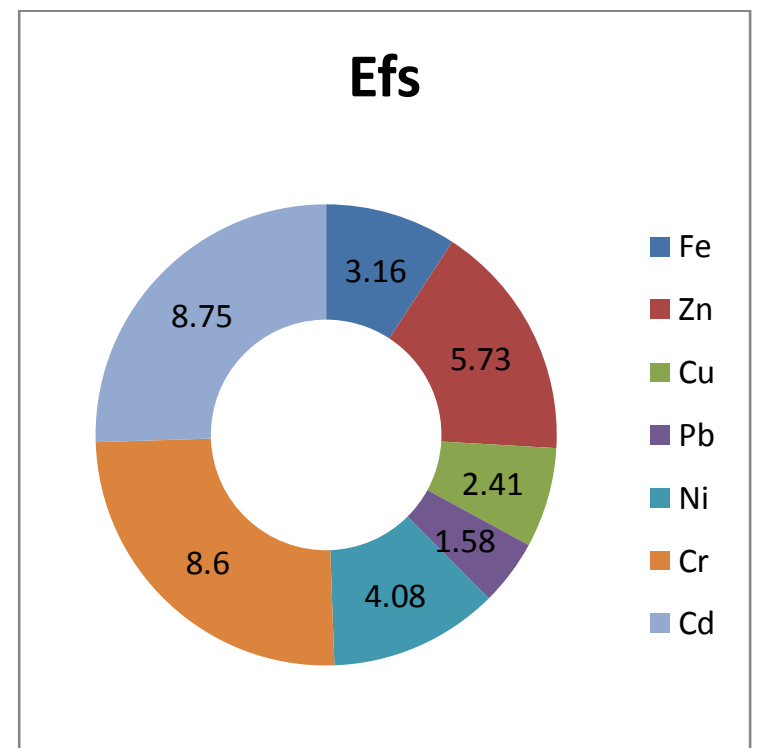

Fig.3: Enrichment factor of soil (Efs) of different trace elements

The consumption of cereal/ grains or leafy plants has high content of $\mathrm{Cr}$ for a long period, shows to cause the fetal disease (Sinha et al., 2006). Chromium is regarded as priority pollutant by USEPA due to its carcinogenicity and mutagencity (Cohen et al., 1993, Cieslak- Golonka, 1995). When such metals laden plants and their foodstuffs are consumed they pose a serious health hazard to human being through food-chain biomagnifications resulting into catastrophic episodes (Nriagu, 1988). The daily intake of such plants that accumulate more toxic elements should be avoided for consumption. Mostly this is very important in the case of edible species particularly leafy vegetables (spinach) and root/tuber vegetables (potato). Whatever the amount accumulated by leafy and root/tuber vegetable, there is a more chance of direct entery into human diet (Kisku et al., 2000). There are many studies where the significantly high accumulation of metal in leaf of the plants was observed (Voutsa et al., 1996). Similarly, Farooq et al. (1999) also observed the accumulation in the vegetables collected from dry bed River in the city of Kanpur and found more accumulation in leafy vegetables than fruit bearing vegetables. Sinha et al.(2006) studied the accumulation of different metals in edible parts of plants and found that accumulation was high in leafy vegetables in comparison to non-leafy vegetable/crops, they also reported that the leafy vegetables were unfavorable to grow in this contaminated agriculture area. Our studies found that the Spinach showed high accumulation of trace elements (Fe821 $\mu \mathrm{g} \mathrm{g}^{-1}$, $\mathrm{Zn} 145 \mu \mathrm{g} \mathrm{g}^{-1}, \mathrm{Cu} 19.84 \mu \mathrm{g} \mathrm{g}^{-1}, \mathrm{~Pb} 18.04 \mu \mathrm{g} \mathrm{g}^{-1}, \mathrm{Ni}$ $10.1 \mu \mathrm{g} \mathrm{g}^{-1}$, Cr $38.32 \mu \mathrm{g} \mathrm{g}^{-1}, \mathrm{Cd} 0.88 \mu \mathrm{g} \mathrm{g}^{-1}$ ) and Wheat showed low accumulation of trace elements (Fe $326 \mu \mathrm{g} \mathrm{g}^{-1}, \mathrm{Zn} 102 \mu \mathrm{g} \mathrm{g}^{-1}, \mathrm{Cu} 8.23 \mu \mathrm{g} \mathrm{g}^{-1}, \mathrm{~Pb}$ $12.6 \mu \mathrm{g} \mathrm{g}^{-1}$, Ni $5.9 \mu \mathrm{g} \mathrm{g}^{-1}$, Cr $21.5 \mu \mathrm{g} \mathrm{g}^{-1}$, Cd 0.21 $\left.\mu \mathrm{g} \mathrm{g}^{-1}\right)$. Plants sample showed higher enrichment factor of chromium $87(\mathrm{Cr})>6.04(\mathrm{Zn})>3.34(\mathrm{~Pb})>$ $3.05(\mathrm{Cu})>2.78(\mathrm{Fe})>2.30(\mathrm{Ni})>\mathrm{BDL}(\mathrm{Cd})$ because tanneries and lather industries situated in polluted area. The result of this study was found that leafy plants may cause high exposure risk than grain. So, leafy vegetables are not suitable to grow in this type of polluted area.

\section{References}

Abdel-Sahab, I., Sehwab, A.P., Banks, M.K. and Hetrich, B.A. 1994. Chemical Characterization of heavy metals contaminated soil in south-east Kasas. Water Air SoilPollut., 78: 73-82.

Akinola, M.O. and Ekiyoyo, T.A. 2006.Accumulation of lead, cadmium and chromium in some plants cultivated along the bank or river Ribila at Odo-nla area of lkorody, Lagos state, Nigeria.J. Environ. Bio., 27: 597-599. 
APHA 2005.Standard methods for the examination of water and wastewater. $21^{\text {th }}$ ed.,American Public Health Association, American Water Works Association, Water Environmental Federation, Washington, D.C.

Boularbh, A., Schwartz, C., Bitton, G. and .Morel, J.L. 2006. Heavy metal contamination from mining sites in south Morocco: 1. Use of a biotest to assess metal toxicity of tailings and soils. Chemosphere, $63: 802-810$.

Barnhart, J. 1997. Occurrence, uses and properties of chromium.Regul.Toxicol.Pharmacol. 26: 53-57.

Barman, S.C. and Lal, M.M. 1994. Accumulation of heavy metals $(\mathrm{Zn}, \mathrm{Cu}, \mathrm{Cd}$ and $\mathrm{Pb})$ in soil And cultivated vegetables and weed grown in industrially polluted fields. J. Environ. Biol. 15(2): 107-115

Barman, S.C., Kisku, G.C., Salve, P. R., Misra, D., Sahu, R.K., Ramteke, P.W.andBhargava S.K. 2001. Assessment of industrial effluent and its impact on soil and plants.J. Environ. Biol. 22(4): 251-256.

Cieslak-Gollonka, M. 1995.'Toxic and mutagenic effects of chromium (VI). A review’, Polyhedron. 15:3667-3689.

Cohen, M.D., Kargascin, B., Klein, G.B. and Costa, M. 1993. 'Mechanism of chromium carcinogenicity and toxicity', Crit. Rev. Toxicol. 23: 255-268.

De, A.K.,Sen, A.K., and Modak, D.P. 1980. ' Some industrial effluents in Durgapur and their impact on the Damodar river', Environ. Inter. 4:101-105.

De, A.K.,Sen , A.K., Karim, R., Irgolic,J., Chakraborty, D., and Stockton, R. A. 1985. 'Pollution profile of Damodarriver sediment in Raniganj Industrial belt, West Bengal, India.', Environ. Inter. 11:453-458.

Farooq, M., Hans, R. K., Viswanathan, P.N. and Joshi, P.C. 1999.'Health hazard from dry river bed agriculture', Bull.Environ.Contam. Toxicol.62:555-562.

Gothberg, A., Greger, M. and Bengtsson, B.E.2002. Accumulation of heavy metals in water spinach (Ipomoea aquatica) cultivated in the Bankok region, Thailand. Environ ToxicolChem 21: 1934-1939.

Greger, M. and Lofstedt, M. 2004.Comparison of uptake and distribution of cadmium in different cultivars of bread and durum wheat.Crop. Sci. 44: 501-507.

Hooda, Vinita. 2007. Phytoremedation of toxic metals from soil and waste water.,J. Environ. Biol. 28: 267-376. 2490.1981. Tolerance limits for industrial effluents discharged into the inland surface waters.

Kannan, V., Ramesh, R. and Kumar, C.S. 2005. Study on ground water characteristics and the effect of discharge effluents from textile unit a Karur District. J. Enviro. Bio. 26: $269-272$.
Karagul, R., Samandar, A., Yilmaz, M., Altun, L. andGedikle, R. 2005. Evaluating the seasonal changes of some water quality parameters of the BuyukMelen river Basin (Duzce, Turkey). J. Environ. Biol. 26: 179-185.

Khwaja, A.R., Singh, R. and Tandon, S.N. 2001. Monitoring of Ganga water and sediments vis-à-vis tannery pollution at Kanpur (India): A case study, Environ.Moni Assess. 68 (1): 19-35.

Kisku, G.C., Barman, S.C. andBhargava, S.K. 2000. Contamination of soil and plants with potentially toxic elements irrigated with mixed industrial effluent and its impact on the environment. Water Air Soil Pollut. 120: 121-137.

Kolay, A.K. 2000.Basic Concepts of Soil Science, $2^{\text {nd }}$ Edn.New Age International (P) Limited, Publishers, NewDelhi.

Kotas, J. and Stasicka, Z. 2000. Chromium occurrence in the environment and methods of its speciation, Environ.Pollut. 107: 263-283.

Li, Y.M., Chaney, R.L., Brewer, E.P., Angle, J. S. and Nelkin, J. 2003. Phytoremediation of nickel and cobalt by hyper accumulator Alyssum species grown on nickelcontaminated soils.Environ. Sci. Technol. 37: 1463-1468.

Malaviya, Piyush and Rathore, V.S. 2007. Seasonal variations in different physico- chemical parameters of the effluents of century pulp and paper mill.Lalkuan, Uttarakhand. J. Enviro. Biol. 28: 219-224.

Memon, A.R., Aktoprakligil, D., Ozdemir, A.andVertil, A. 2001. Heavy metal accumulation and mechanisms in plants. Turk. J. Bot. 25: 111-121.

Mishra, V. and Pandey, S.D. 2005. Immobilizationof heavy metals in contaminated soil using non-humous soil and hydroxyapetitle. Bull. Environ. Contam. Toxicol. 74: 725731.

Nath, K., Saini, S. and Sharma, Y.K. 2005. Chromium in tannery industry effluent and its effect on plant metabolism and growth.J. Environ. Biol.26: 197-204.

Nielsen, F. H., 1998. Ultra trace element in nutrition. Current knowledge and speculation, J. Trace Elements Exp. Med. 11: $251-274$

Nriagu, J. O., 1988. A silent epidemic of environmental metal poisoning ,Environ. Pollut.50: 139-161.

Raj, E.M., Sankaran, D.P., Sreenath, S.K., Kumaran, S.and Mohan, N. 1996. Studies on treated effluent characteristics of a few tanneries at Crompet, Madras. Indian, J. Environ. Protect. 16: 252-254.

Ray, M., Barman, S.C. and Khan, S. 1988. Heavy metal accumulation in rice plants: Adaption to environmental 
stress and consequent public health risk. In :Qzturk MA (ed) Plants and pollutants in developed and developing countries, Proc. Inter. Symp. Izmir, Turkey, 421-441.

Ray, M. and Banerjee, S. 1983. Impact of water contaminated with various industrial pollutants on rice cultivation. $\boldsymbol{J}$. IPHE, India. 1: 1-7.

Sahu, R.K., Kitiyar, S., Tiwari, Jaya and Kisku,G. C. 2007. 'Assessment of drain water receiving effluent from tanneries and its impact on soil and plants with particular emphasis on bioaccumulation of heavy metals.' J. Environ. Biol. 28(3): 685-690.

Singh, Anil K., Misra, Poonam and Tandon, P.K. 2006.Phytotoxicity of chromium in paddy (Oryza sativa L.) plants.J. Environ. Biol. 27: 283-283.

Singh, S., Sinha, S. 2004a. Morphoanatomical response of two cultivars of Brassica juncea (L.)Czern Grown Tannery waste amended soil, Bull. Environ. Contam.Toxicol. 72: 1017-1024.
Sinha, S., Pandey, K., Gupta, A.K. and Bhatt, K., 2005. Accumulation of metals in vegetables and crops grown in the area irrigated with river water. Bull Environ Contam Toxicol. 74: 210-218.

Sinha, S., Gupta, A.K., Bhatt, K., Pandey, K., Rai, U.N. and Singh, K.P. 2006. Distribution of metals in the edible plants grown at Jajmau, Kanpur (India) receiving treated tannery wastewater: relation with physico-chemical properties of the soil. Environ Monit Assess 115: 1-22.

Temmerman, L. O., Hoenig, M. and Scokart, P.O. 1984.Determination of "normal" levels and upper limit values of trace elements in soil, $Z$. Pflanzenernahr.Bodenkd. 147: 687-694.

Voutsa, D., Grimanis, A. and Samara, C. 1996. 'Trace elements in vegetables grown in an industrial area in relation to soil and air particular matter', Chemosphere. 94: 325-335. 